\title{
Africa: A Continent on the Edge, from Skewed Elections to Illiberal Democracies
}

\author{
Abiodun Odusote, $\mathrm{PhD}$ \\ A Senior Lecturer with Public Law Department \\ Faculty of Law, University of Lagos, Nigeria \\ E-mail: aodusote@unilag.edu.ng
}

Received: Feb. 27, 2019 Accepted: March 17, 2019 Published: April 16, 2019

doi:10.5296/ijssr.v7i1.14669 URL: http://dx.doi.org/10.5296/ijssr.v7i1.14669

\begin{abstract}
The conduct of regular elections at pre-determined time is a hallmark of liberal democracy. Most African countries now conduct regular elections. However, it is generally agreed that liberal democracy is not measured only by the conduct of elections but by a consistent commitment to certain democratic and constitutional ethos. The practice of liberal democracy is a commitment to the rule of law, free, fair and credible elections, transparency and good governance among others. In Africa today, it is generally agreed that despite majority of the countries achieving democracies, bad governance, lack of development, inequalities, exacerbation of internal conflicts, and human suffering are pervasive. Scholars have argued that African countries have generally not enjoyed complete freedom despite the periodic conduct of seeming elections in many African countries. The practice of democracy in Africa has been characterized by hooliganism, banditry and citizen frustrations, leading some commentators and scholars to question the suitability of liberal democratic norms within the African space, while some other scholars advance arguments for the justification of hybrid regimes as a variant of democracy suited for the African space. This research therefore seeks to interrogate the factors exacerbating hybrid regimes in Africa, examines the suitability or otherwise of hybrid governments in Africa, the implications of hybrid regimes for constitutional development, inclusive development and further seek the reconciliation of formal democratic practices with substantive democratic practices in Africa. Enquires will be made on how democratic institutions can synergize with democratic government to deliver the dividends of democracy to the people, how democracy can impact the people and how democracy can deliver good governance and create commonwealth for the citizenry. This paper acknowledges the difficulties of seeking a uniform constitutional template that promotes liberal democracies across African states. However, this paper suggests basic constitutional democratic baseline that has the potential of meeting the fundamental
\end{abstract}


aspirations of the African people.

Keywords: Hybrid regime, illiberal democracies, elections, inclusiveness, and constitutionalism 


\section{Introduction}

Generally, in contemporary times elections are conducted and more frequently in most African countries but such elections are pre-determined in favour of the incumbent and characterized by corruption and intolerance of dissenting views. This has occasioned violent clashes, loss of lives and destruction of properties during and after elections in most African states, particularly in Egypt, Zimbabwe, Sierra Leone, Côte d'Ivoire, Gambia, Kenya and Nigeria. In addition, the prevalence of sit-tight president across African countries undermines the credibility of the elections being conducted in these countries. In Cameroon Paul Biya, 86, has been in power since 1982. Jose Eduardo dos Santos, 76, has been President of Angola since 1979 and left in 2017, Teodoro Obiang Nguema Mbasogo, 76, has ruled Equatorial Guinea for almost 40 years, Yoweri Museveni, 74, became Uganda's president in 1986, the Constitution was amended, scrapping presidential term limit and age limit, to allow him to extend his time in office. In Rwanda, the Constitution was amended in 2015 to allow Paul Kagame who took office in 2000 to continue in office till date. In West Africa, Gambia's Yahya Jammeh was forced to leave office after he had refused to step down following his defeat in the December 2016 election. In Nigeria, former President Olusegun Obansajo unsuccessfully pushed for a tenure elongation. Can the political shenanigans in these African countries be described as a variant of democracy? It is doubtful. These practices are more of pretences to democratic practices.

In most of these African countries, the constitutions and legal frameworks permit liberal democracy, also known as constitutional democracy, imbibing the attributes of representative democracy with the hope of enhancing and facilitating national progress and development. Key principles of liberal democracy include; one vote of equal value in a free and fair elections, presence of multiple and distinct political parties, application of the rule of law; an independent judiciary, and a system of checks and balances between branches of government, entrenchment of fundamental human rights, abolition of corrupt practices and abuse of power, ensuring suitable and adequate shelter, food, and health care. However, the entrenchments of these ideals and aspirations in the constitutions have in no way translated to the practice of truly liberal democracy, national unity and development. It is clear that other liberal democracies across the globe have developed technologically and scientifically and have done so because they have paid more than verbal commitments to these concepts. Nigeria and other African countries are in a state of considerable flux; corruption abounds; education is deteriorating at all levels; there is prevalence of massive election rigging; collapsed infrastructures are noticeable everywhere; homelessness and shanties are on the rise; infringement of fundamental human rights abound; there is general insensitivity to workers' plight; the sitting governments at all levels have strong influences over election outcomes and there is ambience of insecurity in the North Western states of Nigeria, Kenya, Egypt and some other African countries. In these arrears, Africa lags behind most other states that operate constitutional democracy.

Many African countries profess to the practice of liberal or constitutional democracy in theory but in practice, these countries are no more than illiberal democracy, semi despotic or authoritarian. The plausibility of the contention that democracy as practiced in many 
countries in Africa is illiberal can be supported by many examples, because of want of space and time; this paper interrogates the adherence to the rule of law, the independence of the judiciary, elections and electioneering in selected African countries, with particular emphasis on Nigeria. In probing the practice of illiberal democracy in some African countries, practice in Nigeria is extensively examined and experiences from other African countries are engaged. The paper has five segments. Part one is the introductory, part two proceeds to define key concepts; part three explores the factors exacerbating illiberal democracies in Africa. In part four, it is argued that elections and electioneering as conducted in the selected African countries not only undermine the tenets of liberal democracy but exacerbates conflicts and promotes corruption. In conclusion, a call is made for renewed commitments to democratic values by African politicians and the electorate and strengthening of democratic institutions that support and give meaning to liberal democracy.

\subsection{Theories of Democracy}

There are three relevant contemporary theories of democracy relevant to this research; the Elite theory, the Pluralist theory and the Participatory theory. These theories underpin the discourse and analysis in this paper. The Elite theory opines that the masses are incapable of making rational decisions on major national issues. The Pluralist theory responds to and rejects the Elite theory of exclusiveness inherent in the Elite theory, the Pluralist theory opines that no single group should dominate politics but suggests that organized groups should compete with each other to influence policy decisions, hence promoting inclusiveness. Individuals are encouraged to work through their respective groups to influence and contribute to politics. Participatory theory opines that citizens have the power to make policy decisions. Participatory theory emphasizes the broad participation of people in politics. In a participatory democracy, citizens do have the potential to influence policy decisions, but do not make policy decisions. However, despite the pre-eminence and significance of these theories there is an emerging trajectory of citizen apathy towards elections, democracy and politics around the world (Rosenberg, 2007)

\subsubsection{Methodology}

This research adopts the use of doctrinal and qualitative research methodologies to analyze existing data, theories, case law and norms relevant to the discourse.

\subsubsection{Significance of Study}

The findings of this study will benefit Nigeria in particular and African countries at large. There is established matrix between illiberal democracy, bad governance and underdevelopment in Africa. The urgent need for good governance, transparency and inclusiveness across African countries justify the need for a demand for liberal and participatory democracies. The recommendations of this study will help African countries and the citizens appreciate the need for citizenship engagement with governments and discourage voters' apathy during elections. It will help discourage and reverse the spread of elite theory of democracy in Africa and lay the foundation for liberal democratic governance across the continent. 


\section{Conceptual Terminologies}

\subsection{Democracy}

President Abraham Lincoln (1963) famously described democracy as government by the people and for the people. In its most basic definition, it is government by the people for the people. Since then, the terminology had been defined extensively by various scholars. The common denominator however is that democracy is a form of government in which power and authority are vested in the representatives of the people. Democracy abhors despotic tendencies. The representatives must have assumed power through a free and fair election. (Oyebode 2009) identified the appurtenances of democracy as separation of powers, adult suffrage, freedom of speech and of the press, equality before the law, an independent judiciary, right of dissent, etc. In the absence of these pillars there cannot be democracy.

\subsection{Liberal Democracies}

Democracies are political systems underpinned by strong, independent efficient public institutions including a fearless incorruptible judiciary, separation of power, checks and balances, application of rule of law, free fair and credible elections, and party system. Liberal democracies connote that political parties are open and transparent, competition is free from violence, and executive power is strongly constrained by functional and effective institutions, such as, independent courts and powerful legislatures are more stable(Fagbohun, 2008).

\subsection{Illiberal Democracies}

The concept of illiberal democracy has generally been ascribed to Zakaria (1997). In his paper titled, "the Rise of Illiberal Democracy," Fareed argued that constitutionally elected governments across the globe often exceed their constitutional limits by depriving citizens their basic rights and constitutional freedoms. He cited Kazakhstan and Belarus as near-tyrannies and mentioned Argentina as modest offender. Examples of illiberal democracies abound in Africa; chronic cases of Zimbabwe, Cameroon and Togo attest, and the milder form of illiberal democracy exist in Nigeria. The first group consists of regimes that came to power by armed force, and have allowed guided electoral competition, but hold the ace to crush political rivals without any negative consequences to the regime. These are regimes that pretend to take over power through democratic means but ignore constitutional limits when they assume power. They often use state apparatus to disenfranchise other rival groups. Other similar terminologies for illiberal democracies include hybrid regimes, empty democracy and competitive authoritarian regimes.

A hybrid regime is a combination of democratic and authoritarian elements (Diamond, 2002). The sovereign power has near absolute powers bothering on near-tyrannical rule. The political elites in the corridors of power enacts laws that suits and keep them in power (Elite theory of democracy). They hijack state and institutional apparatus to perpetuate their stay in power and create a political dynasty around themselves. In explaining this concept, Levitsky and Way postulates:

Competitive authoritarian regimes are civilian regimes in which formal 
democratic institutions exist and are widely viewed as the primary means of gaining power, but in which incumbents' abuse of the state places them at a significant advantage vis-à-vis their opponents. Such regimes are competitive in that opposition parties use democratic institutions to contest seriously for power, but they are not democratic because the playing field is heavily skewed in favor of incumbents. Competition is thus real but unfair. (2010)

However, the concept of illiberal democracies has been challenged by some scholars (Muller, 2016; Kornai, 2015; János Kis, 2014). They contend that the traits of illiberal democracies are not characteristics of a democratic typology. They contend that there is no democracy outside liberal democracy, a regime that is characterized by abuse of power, disenfranchising the opponents, lack of transparency, manipulation of state apparatus and institutions to gain unfair advantages cannot be a democratic government. This augment is seemingly logical. For a government to ascribe the ideals of democracy to itself there has to be minimum compliance with the ideals of democracy which include, free and fair elections, tolerance of opposing views, freedom of speech and association, independent judiciary and legislative arm that is independent enough to perform its oversight functions. Democracy cannot be attained through banditry, political hooliganism and election manipulation. Human rights must be guaranteed and respected. Liberal democracies that habitually produce illiberal outcomes cannot be properly described as a democracy. For example, the regime of Robert Mugabe of Zimbabwe was more authoritarian than democratic despite the pretence to regular elections. There is also Paul Biya in Cameroons who has held his country together with iron fist and had perpetuated stagnancy for almost four decades. In this bracket Paul Kagame of Rwandan is included, though he has done brilliantly by transforming his country from the ruins of a brutal genocide but Kagame is sliding towards being a despotic regime. He has been in office since 1994. He contested and won the last election by amending the Constitution, permitting him to serve more than two terms. Allegations of brutality and oppression of opposing view has been levied against him (Himbari, 2015).

\subsection{Constitutionalism}

It denotes that the state and the individual should conduct their affairs according to the Constitution. This concept reduces individuals and the state and emphasizes a collection of values and institutions that are superior. These values include the observance of the rule of law, and complete adherence to constitutional provisions. These values connote that rulers are limited and constrained by the provisions of the Constitution. Hence, arbitrary rule and rule of force is an aberration to Constitutionalism (Oyewo, 2016). This concept has been explored by various scholars from diverse perspectives. It complements the political theories of John Locke and the rule of law. Jon Roland argues that constitutionalism demands that the Constitution must be maintained at all cost, and in every particular, that the Constitution is more important than human lives, even millions of them, he argues that when human dies, the Constitution remains alive, (Pennock \& Chapman, 1979).

A remarkable perspective is that firm stance should always be taken against the violations of 
any provision of the Constitution, (Vol. 1, No. 6, n.d). Bo Li puts it more succinctly, "tyrants will not become benevolent rulers simply because the Constitution tells them to. In order to guard against violations against the letter and spirit of the Constitution, there needs to be a set of institutional arrangements." This paper addresses the issue of violation of constitutional provisions with impunities in the African space.

The traditional meaning of constitutionalism denotes a form of restraint to check the arbitrariness or excesses of government. Mcllwain (1974) describes constitutionalism as a 'legal limitation on government, it is the antithesis of arbitrary rule; its opposite is despotic government, the government of will instead of law. In a liberal democracy an effective and robust legal framework is a prerequisite for national integration, national progress, and national unity. It provides the minimum basis for creating rule-bound states, and discipline on the part of governments, markets and citizens (CDD-Ghana, 2001) Effective legal framework is imperative for curbing executive lawlessness, elimination of uncertainties in dealing with government and its agencies, attraction of foreign investments, transfer of technology and friendly business environment.

The sustenance of constitutional democracy demands that the government ensures proper nurturing and strengthens those institutions and 'mechanisms that uphold democracy- these include the judiciary, the electoral body, Human Rights Commission, virile political parties with comprehensible manifestoes, vibrant and free media and an engaged civil society'(Hirnyam, 2011:4).

Effective legal framework facilitate the establishment of unifying values and societal goals, enhancing government stability, protecting basic freedoms and rights, and promote Democracy, National Progress and Development. A constitutional democracy exists when these rules and principles are followed consistently.

Constitutional democracy must be underpinned by constitutional structure which guarantees fundamental freedoms and rights. "An enabling legal and regulatory framework is one in which laws and regulations are clear, transparent, and applied uniformly, and in a timely manner, by an objective and independent judiciary". In sum, legal framework in a constitutional democracy serves two major purposes; it provides for key public institutions and their roles in sustaining democratic values and also serves as the key stone and defining feature of a liberal democracy. 'An effective constitution, therefore, requires not merely the existence of constitutional rules, but also the capacity of those rules to constrain government and establish robust constitutionalism'.

\subsection{National Development}

National development is understood to mean the general well-being of the population, including, socio-economic realization, civil and political freedoms national integration, and cohesion. By national development is meant a gradual advance or growth through progressive changes (Idowu, 2008). This simply put, is the ability of a nation to improve the lives of its citizens. National development can be measured by the people's quality of life: access to education, employment, health care, shelter, life expectancy, and good governance. In sum, 
National development incorporates all aspects of the citizens' well-being, health status, secured environment, literacy and economic well being.

Against this background, this paper sets out below analysis of democracies in Africa and its correlation with progressive development. This research enquires into how scholars have answered some pertinent questions on constitutional and developmental theories. For example, what is the relationship between liberal democracy and development? How is Constitutionalism related to development? Is there any matrix between these three concepts? Which of the above identified theory will enhance democracy and good governance in Africa?

\section{Factors Exacerbating Hybrid Regimes in Africa}

\subsection{Non Adherence to Rule of Law}

Rule of law is the bedrock of a civilized society. It is the bedrock of democracy and democratic practices (Shivute, 2009). In the absence of rule of law, there will be anarchy, self-preservation, and the fittest for survival. This will be no less than the system of governance in the animal kingdom or better still a semblance of the animal farm democracy. Development and industrialization will be century away from a country that berates the rule of law. African heads of state and government have the obligation to uphold the rule of law (AfCHPR; ACDEG).

A country that practices constitutional democracy must treat the rule of law with utmost respect and as sacrosanct. Rule of law is an embodiment of the supremacy of law, equality before the law, action according to the law, and independent judiciary (Olaide \& Adewoye, 2010). The rule of law is the basis of a democratic government; for everything else depends on it: a vibrant economy, a free and fair election, an independent judiciary, and national development. Unfortunately, the application of the rule of law in most African countries has not been very encouraging due to many years of military and despotic rules that have eroded the principles of separation of powers amongst organs of government (Oyebode, 2009). The Supreme Court of Nigeria emphasized the importance of the rule of law as a panacea for good governance and sustenance of democracy in the case of Military Governor of Lagos State and other v. Chief Emeka Odumegwu Ojukwu (1986) All N.L.R 233 Oputa JSC held that the state is subject to the law and governments should respect the right of the individual citizens under the rule of law. Rule of law is the cornerstone of a liberal democracy.

Factors undermining democracy, peace and security in Africa include the absence or failure of the rule of law. The Chief Justice of Nigeria, Hon. Justice Walter Onnoghen, GCON, succinctly stated:

There is a mutual and reinforcing correlation between the terms, rule of law, peace, security and good governance both in theory and practice. The concept of rule of law, just like other features of liberal democracy such as accountability, transparency, and protection of human rights is a crucial element of democracy, the absence of which may spell doom for any democratic system (2018:2-3). 
It is however saddening that most democracies in Africa holds the application and practice of rule of law in contempt and disdain. For example, in Zimbabwe, people responsible for the murder of white Zimbabwean farmers during the land invasions have not been prosecuted till date and it is reported that the people responsible for the death seemingly enjoy government protection (Cross, 2017). In Egypt findings have shown increase in corruption, decrease in the enjoyment of the rights to freedom of expression and privacy, decrease in judicial and legislative oversight, decrease in labour rights, security and safety, as well as a decline in due process of law (World Justice Project, 2017-18). These are not isolated cases, in a research conducted by Mo Ibrahim, rule of law has declined for $70 \%$ of Africans over the past decade, 33 out of African 54 countries had experienced a decline (IIAG, 2018).

In Nigeria, Mr. Dasuki former National Security Adviser to the Federal Government is facing multiple charges under the succeeding government for alleged diversion of \$2.1 billion and illegal possession of fire arms. He has been granted bail by different courts but the Federal Government has persistently refused to comply with the court orders. In addition, the ECOWAS court granted the former NSA bail and ordered the Nigerian government to pay damages on October 4, 2016. The government has failed to comply with the court orders till date (Okakwu, 2016). Also, Mr Ibraheem El-Zakzaky, a leader of a Shiite group, and his wife have been in detention without any trial for over 17 months. The Federal High Court ordered his release when he challenged the violation of his human rights, till date he is still in detention (Tribune, 2016). In AG Lagos v. AG Federation, (2004) 12 SCJN 1, Niki Tobi, JSC (as he then was) criticized the Federal Government for resorting to self-help rather than the court of law over a dispute between it and the Lagos State Government over the failure to remit funds allocation meant for Local Government Councils in Lagos. His Lordship stated:

If the federal government felt aggrieved by Lagos State creating more Local Governments, the best solution is to seek redress in a court of law, without resorting to self-help. In a society where law prevails, self-help is not available to the Executive or any other arm of government. In view of the fact that such a conduct could breed anarchy and totalitarianism, and since anarchy and totalitarianism are antithesis to democracy, courts operating the rule of law, the lifeblood of democracy, are under a constitutional duty to stand against such action.

This dispute between the Lagos State Government and the Federal Government is typical example of executive lawlessness in Nigeria despite the pronouncement of the apex Court on the matter the Federal Government was still defiant.

\subsection{Suppression of the Opposition}

The right to hold a contrary political opinion is guaranteed by the Constitution and it is a hallmark of the practice of democracy. Section 38(1) of the 1999 Constitution provides that:

Every person shall been entitled to freedom of thought, conscience and religion, including freedom to change his religion, belief, and freedom (either alone or in community with others, and in public or in private) to manifest and propagate his religion or belief in worship, 
teaching, practice and observance.

Suppression of opposition is antithetical to liberal democracy. Tolerance and accommodation of opposing views is essential for the nurturing of democracy. However, vicious and violent attacks on opposition have been documented across African states that profess to be practicing democracies. Including the use of excessive force by Ethiopian security forces, to disperse peaceful protests in Oromia in November 2015, which later escalated to other regions, government forces later banned all protest and blocked internet access. In Zimbabwe until the recent ouster of Mugabe excessive force and detention of opposition members was the norm. Similar attacks have been reported on opposition in Chad, Republic of the Congo (Congo), DRC, Ethiopia, Gabon, Lesotho and Uganda. "A draft law under parliamentary consideration in Mauritania restricted the right to freedom of peaceful assembly and association. In Congo, a law increasing government control over civil society organizations was passed. In Angola, the National Assembly approved five draft bills that will impermissibly restrict the right to freedom of expression" (Amnesty International, 2016/17". In Nigeria, it is recalled that agents of state during President Goodluck Jonathan's tenure prevented both Governors Amaechi and Oshimole from participating in the APC's mass rally aimed at increasing support for former Governor Kayode Fayemi few days before the gubernatorial election in Ekiti State. Amaechi and some other leaders of the APC were prevented by state security operatives from entering Ekiti State, while Oshmole's plane was prevented from departing the Benin Airport. State security operatives were also allegedly used to harass, intimidate and beat up opposition members. Same accusations are now being levied against the APC government of President Buhari. It has been alleged by commentators that Dasuki and others are being vilified because they served the Jonathan's administration under the Peoples Democratic Party (PDP), more particularly that the former Secretary to the Government of the Federation (SGF), David Babachir Lawal and the Director General of the National Intelligence Agency (NIA), Ayodele Oke are not facing trials even after being indicted by administrative panels and being removed from office. These practices create the impression that some people are favoured and above the law, thus entrenching multiple standards in the application of law. It undermines the integrity and inviolability of law and its ability to ensure orderliness in a democracy. This contemptuous disdain for the rule of law is prevalence across democracies in Africa.

\subsection{Violations of the Principle of Judicial Independence}

One of the cardinal principles of democracy is separation of powers between the three organs of government, the executive, legislative and judiciary. Judiciary occupies a strategic position in the sustenance of democracy, (Olaide \& Adewoye, 2010). For the judiciary to perform its duties effectively, it must be independent of other arms of government. For a constitutional democracy to be meaningful and relevant, the ordinary citizen must be able to access justice within a reasonable time. There must be a functioning, efficient and independent judiciary. This principle is expressed in The Bangalore Principles of Judicial Conduct:

A judiciary of undisputed integrity is the bedrock institution essential for ensuring compliance with democracy and the rule of law. Even when all other protections fail, it provides a bulwark against any encroachments on its rights and freedoms under the law. 
Democracy, peace and development can only thrive when citizens have effective access to redress their grievances. Section 6 of the 1999 constitution vests adjudicative powers in the judiciary. The judiciary appears to be the most effective and credible arm of government; quietly playing its role as a veritable tool of development.

There is no doubt that the judicial approach to the interpretation of the 1999 constitution has been largely activist. The period of last 10 years of democracy in Nigeria has witnessed a revolution in the judicial sector, transforming it into, by far, the most credible arm of the government, (2002).

\subsection{Many Challenges of the African Judiciary}

African judiciary has been plagued by problems and intractable challenges by the executive including, declining standard of legal education; corruption, high handedness by the executive and the pursuit of money and material gain to the exclusion of noble ideas and ideals by some judicial officers.

The highlighted problems are not closed. It includes incessant adjournments by courts; appointment of incompetent judges, and corrupt judges. For example, a judge sitting at night to upturn a free and fair election and injunction-for-the-highest-bidders are vices that have contributed to the general perception that the judiciary is corrupt. The criminal justice administration of Nigeria is a matter for concern. It is absolutely failing Nigeria. Most of the people in prison are yet to be convicted of any offence; there is double standard in the treatment of affluent people and the poor, while the rich and the affluent may be entitled to plea bargaining, the poor and neglected have never been offered the opportunity to plea bargain. Prolonged detention is common practice (Amnesty International, 2008).

Political interference is a major hindrance, the beating up of a sitting judge of the High Court by Ekiti State governor and his political associates within the court premises (PM News, 2014) lend credence to the practice of illiberal democracy in Africa, equally the manner in which Hon Justice Walter Onnoghen, the then Chief Justice of Nigeria was suspended from office in 2019 at the period leading towards the general elections, without regards to the due process of law and judicial independence is worrying. Arrest of judicial officers by the Directorate of State Security, DSS, including the arrest of Federal judges, and three honorable justices of the Supreme Court for corruption related charges without following due process is an assault on democracy on independence of the judiciary and rule of law. The DSS powers, as enumerated in sections (2) (3) and (6) of the National Security Agencies Act 1986 does not include the investigation and prosecution of corruption and abuse of office. Section 153(1) (I) and part 1 of the Third Schedule of the 1999 (as amended), establishing the National Judicial Council, NJC vests the NJC with powers to regulate and discipline judicial officers in the country (Section 160 of the 1999 Constitution). Section 158 (1) of the 1999 Constitution of the Federal Republic of Nigeria provides for the independence of the Judiciary. It has also been shown that interference with judicial independence by the government is the norm in Ethiopia, Mozambique, Swaziland and Angola (Ashenafi, 2003). 


\section{Elections and Electioneering as Albatross}

Free and fair election is the bedrock of constitutional democracy. A credible election underpins credible democratic leadership. The importance of electoral systems lies in its role of being one of the fundamental institutions in a democracy. It is generally agreed by commentators and scholars that elections in most African countries are always marred in controversies at every stage. The leadership of the political parties selects their flag bearers, without conducting any primaries. The incumbent uses state resources to oppress and silence opposition. Killings, arrest, maiming and enforced disappearance of opposing candidates before and during elections have been recorded in Zambia, Kenya, Ethiopia and many other African countries (McCrummen:2008; HRW: 2004). Research has equally shown that the opposition parties are not blameless, all the parties fiercely contest to outdo each other in electoral malpractices i.e. ballot stuffing, multiple voting, bribery, gun pilling, violence, banditry, and assassination are common place among the politicians across the parties and in Africa (Wondwosen:2008). Hooliganism pervades the electoral space; the politicians also employ the services of unemployed youths as militia to support their political aspirations. In the extreme, ethno-religious diversity is often manipulated to create tensions in the polity. These are signs of empty democracy, a democratic process that is not owned by the majority of the people. Research has shown that an electoral system that does not embrace participation of tolerance of oppositions, freedom of expression, freedom of association, and universal suffrage cannot produce a credible democracy (Dahl, Poliarchy: 1971; Lijphart:1999). The result is a government that is not accountable or responsive to the needs and aspirations of the people.

In addition, civilized electioneering and manifesto presentation is almost non-existence, political posters and manifestoes are filled with meaningless campaign clichés, devoid of any meaningful ideology or promises to the electorate, such as 'now ready for national assignment,' 'trusted and reliable.' The essence of democratic election is that it must be free and fair. Free and fair elections cannot tolerate hooliganism, politically motivated killings and banditry. During the 2015 general elections in Nigeria it was reported that over 800 people were killed during the elections, (HRW, 2018). At the just concluded presidential election many people have been reported killed, including an Independent National Electoral Commission official (Onwuka, 2019).

The aforementioned vices are antithetical to development and good governance, in other constitutional democracy across the globe, electioneering is issue-driven. Politicians engage in constructive debate on concepts like, immigration, death penalty, abortion, education, industrialization, privatization, economy.

It is difficult for credible leadership to emerge from this screwed electoral system. The electoral system in Africa encourages worst form of elite theory of democracy. It is only the few privilege individuals in power that take decisions for the benefit of all. The matter is made worse by reason of the fact that no law enforcement agent has the temerity to arrest any of these politicians and prosecute them for criminal offences. Some years back, a prominent politician at Ibadan was caught with INEC's electoral items; no one has been prosecuted till 
date. In Nigeria political assassinations of the Igwes, Funsho Williams and Bola Ige remain unsolved. These appalling and barbaric attitudes will not bring Africa the changes it needs to strengthen stability and development. These anomalies have the potential to deepen the vulnerability of Nigeria to conflict, and further alienate citizens from the political elite and reinforce violent group. It has been observed that there is a correlation between lack of credible elections in African states and the widespread collapsed of infrastructure, total paralysis of the health sector at all levels, constant nationwide power failure, pervasive unemployment, increased armed robbery, debilitating homelessness, retrogressive educational programmes and policies, (Gani:2008).

In sum, the absence of democratic choice, the lack of institutionalization of accountability, the lack of any meaningful form of popular participation makes any prospects of changing the government by peaceful means near impossible, to most African countries pluralist theory of democracy does not apply. All organized groups and opposition, including the civil societies are being suppressed illegally. "Without a veneer of legitimacy, the government is delinked from the society and alienated from it. This makes the mobilization of the society for development impossible.'(Ake, 1989:46) This has led to the upsurge of hybrid and Illiberal regimes across Africa. Hybrid governments across African countries are a key source for internal conflicts, corruption, human trafficking, modern slavery and instability in African countries Annan, (2014). Most African governments are failing to satisfy the basic needs and aspirations of the electorate. Available literature are in agreement that most African countries are lacking in key component of liberal democracy, including regular free and fair credible elections, party structure, party financing, autonomous, transparent and effective public institutions. These key components are the pillars of liberal democracy. Democracies that are not built on these key components are bound to be flawed and regressive.

\subsection{Party System}

The party system is another pillar of democracy. Political parties are necessary in democracies to form ideologies, train and sponsor their members as candidates for elective positions. In addition, political parties are expected to form opposition parties after having lost general elections to curtail the ruling party's excessive, and present credible alternatives to the electorate (Dolo, 2006). However, because the candidates, and the different parties, exhibit no ideological differences, most times, election campaigns revolve around ethnic and religious identity. And as long as ethnic and religious divisions persist the citizenry will continue to be manipulated by the elite for political advantage thereby enhancing the Elite theory of democracy. In addition, parties are built around strong individuals who are often the sponsors of the parties and are not accountable to party members (Chege, 2007). This practice is similar to the proposition of Elite theory of democracy in which a small number of people, usually those who are wealthy and well-educated, influence political decision making. These individuals are known as god fathers. They impose party candidates on the members, internal party democracy is nonexistent. Parties across African countries are generally fragile, structurally weak, lack adherence to rules, transparency and decorum. These factors have generally occasioned exclusiveness, oppression and party system instability in Africa. Sarah Birch, rightly posited that a party system instability has four main consequences that are 
detrimental to democratic practices; "it reduces accountability, it impedes party institutionalization by decreasing the level of long-term commitment which politicians, activists, and voters have to 'their' party, it significantly increases uncertainty, hampering the ability of politicians and voters to engage in strategically-driven co-ordination, and It raises the stakes of the electoral game. This may have the consequence of weakening the democratic commitment of politicians who may seek other ways of feathering their beds so as to insure themselves against possible political loss at the next election"(Birch, 2002). This opinion is supported by Oguntade, JSC in the case of Ugwu \& Anor v. Ararume \& Anor (2007) 4 S.C.(Pt 1) 88 where he opined that the constant failure of the political parties to ensure intra-party democracy and live by the provisions of their constitutions in relation to the emergence of candidates for election is one of the major impediments to the practice of liberal democracy in Africa and the enthronement of illiberal democracies.

\section{Concluding Findings on How Democracy Can Deliver Good Governance}

As shown above, the claim to democracy has brought some semblance of political stability to Africa. However, democratic values as inherent principles of liberal democracy are nonexistent in most of these African countries. For democracy to be sustainable it must be natured and sustained in its ideal state. The citizenry must have value for their mandate. This paper shares the opinion of the Participatory theory of democracy that conceives democracy as an activity through which citizens participate in politics for the development and enhancement of their livelihoods. Active participation by the people is desirable to curb the continued widespread of illiberal democracies influenced by the Elite theory of democracy in Africa. Active engagement of the masses in politics will guarantee inclusive democracy. The populace should realize that political cynicism as witnessed in the just concluded 2019 general elections in Nigeria is antithetical to development and good governance. The just concluded 2019 general elections in Nigeria witnessed voters' apathy. Majority of the electorates did not partake in the electoral system, thus, inadvertently encouraging the worst form of elite theory of democracy to thrive in Nigeria.

Generally, the incontrovertible and overall conclusion that can be drawn from the above analysis is that most countries in Africa, claim to be constitutional democracies, the ideals of a constitutional democracy is alien to these countries. This paper acknowledges that the legal framework makes provisions for the constitutional platform and institutions that can support liberal democratic values in these countries but the truth is that the established institutions are either too weak or have compromised their integrity to the extent that they are unable to perform effectively. Electoral Commissions in most African countries are too weak as impartial umpires to effectively perform their primary duties of organizing free and fair elections. Electoral Commissions must be independent of the executive arm of government in its finance and the appointment of its principal officers. In most African countries, electoral bodies are appointed by the executive.

To reverse this degeneration, there must be proper accountability and citizen engagement. This view supports the participatory theory of democracy. The electorate must ask probing questions from politicians and public officials, enforcement agency must be effective and 
diligent in arresting corrupt officials, there must be proper and thorough prosecution, the masses are tired of mass media trial, a situation where corrupt officials are only arrested and not prosecuted is not good enough.

Africa needs a new political class with a new ideology. A new political class that is willing to abide by the ideals of constitutional democracy. Africa desires strong and sustainable democracy. Politicians and citizens must play by the rules. Democracy will only usher in peace, stability and prosperity where its ideals are respected and observed. Democracy is about more than holding elections is it is about building institutions that support democracy and ensure good governance and respect for rule of law. No investor will be willing to invest in an environment invested with corruption, brutality and oppression.

From the above analysis, it can be concluded that Africa travels in the dark and the road is filled with pot holes. A major departure is required from the political elites and the followership as well. The primitive accumulation of wealth by the political elite must give way to transparency and accountability. The followership needs a re-orientation, they need to hold the politician accountable and be thought not to sell their birth right for a plate of porridge during election campaigns.

\section{Reference}

Ake, C. (1989). The Present Crisis in Africa: Economic Crisis or a Crisis of the State? In O. I. Julius (Ed.), The Political Economy of Crisis and Underdevelopment in Africa: Selected Works of Claude Ake (p. 46). Lagos: JAD Publishers.

Alemika, E. O. (2018). Post-Election Violence in Nigeria: Emerging Trend and Lessons, CLEEN Foundation. Retrieved May 29, 2018, from $\mathrm{http}: / /$ cleenfoundation.blogspot.com/2011/.../post-election-violence-in-nigeria.ht

Annan, N. (2014). Violent Conflicts and Civil Strife in West Africa: Causes, Challenges and Prospects. Stability: International Journal of Security and Development, 3(1), 3. https://doi.org/10.5334/sta.da

Bo, L. (2014). What is Constitutionalism? Perspectives, 1(6).

CDD-Ghana. (2001). Governance, Democracy and Development in Africa: A Critical Approach'being a paper presented by the Ghana Center for Democratic Development at the International Conference on the Cultural Approach to Development in Africa (p. 1). Organized by African Institute for Economic Development and Planning - IDEP - at Dakar, Senegal, 10-14 December 2001.

Dolo, E. (2006) Opposition parties: Benefits and Challenges in Building Democracy. The Perspective, October, 1-8.

Fagbohun, A. (2013). Nigeria's Democracy and the Crisis of Political Instability: An Audit of the Electoral System. Retrieved from https://www.africaportal.org/publications/nigerias-democracy-and-the-crisis-of-politicalinstability-an-audit-of-the-electrical-system/ 
Fareed, Z. (1997). The Rise of Illiberal Democracy. Foreign Affairs, 76(6), 22-46.

Harlow, C. (2009). Law and Administration. Cambridge: Cambridge University Press.

Hirnyam, M. (2011). Constitutional Democracy \& Smooth Succession of Government in Africa. Retrieved June 20, 2011, from http://nigeriamasterweb.com/blog/index.php/2011/03/09/constitutional_democracy_and _smooth_succ

Human Rights Watch. (2018). Nigeria: Post-Election Violence killed 800. Retrieved May 16, 2018, from http://www.hnv.org/news/2011/05/16/nigeria-post-electionviolence-killed-800

Idowu, A. (2008). Human Rights, Democracy and Development: The Nigerian Experience. Research Journal of International Studies Issue, 27.

János, K. (2014). Illiberális demokrácia nem létezik (Illiberal Democracy Does Not Exist). Hvg.hu, November 24.

János, K. (2015). Hungary's U-Turn: Retreating from Democracy. Journal of Democracy, $26(3), 34-48$.

Larry, D. (2002). Elections Without Democracy: Thinking About Hybrid Regimes. Journal of Democracy, 13(2), 21-35. https://doi.org/10.1353/jod.2002.0025

Lewitsky, S., \& Lucan, W. (2010). Competitive Authorianism: Hybrid Regimes After the Cold War. Cambridge: Cambridge University Press.

Mamman, T., \& Okorie, P. (2010). Nurturing Constitutionalism through the Courts: Constitutional Adjudication and Democracy in Nigeria. Retrieved June 7, 2010, from http://www.ialsnet.org/meetings/constit/papers/Mamman\&Okorie(Nigeria).pdf

Mcllwain, C. H. (1940). Constitutionalism Ancient and Modern. Ithaca, NY: Cornell University Press.

Michael, A., Hamdok, C., Per, N., \& Jpram, R. (2007). Political Parties in East Africa: Diversity in Political Party Systems. International IDEA Research and Dialogue Coordination.

Mo, I. (2018). Ibrahim Index of African Governance (IIAG). Retrieved June 10, 2018, from http://mo.ibrahim.foundation/iiag/

Müller, J. (2016). The Problem with Illiberal Democracy. Project Syndicate, January 21.

Olaide \& Adewoye. (2010). The Rule of Law as a catalyst for Sustainable Democracy in Nigeria. Commonwelth Law Bulletin, 36(2), 343-355.

Onnoghen, W. (2018). The Rule of Law as a Panacea for Peace, Security and Good Governance in a Democracy. Public Lecture Series Faculty of Law, UNILAG, 1.

Onwuka, A. (2019) Eections: Watered by blood of Nigerians Nigerian Punch Newspapers. 
Retrieved from https://punchng.com/2019-elections-watered-by-blood-of-nigerians

Oyebode, A. (2009). Constitutional Reform and the Future of Democracy in Nigeria. Paper presented at the Action Congress South West Zone Annual Conference. Ibadan Thursday 19-Friday20 March, 2009.

Oyewo, O. (2016). Sounding the Death Knell of the Public Officer Protection Act/Law in Nigeria. International Journal of Liberal Arts and Social Science, 4(1), 106.

Pennock, J. (1979). Constitutionalism (Roland and John W. Chapman, eds.). New York: New York University Press.

President Abraham Lincoln. (1963). Statement as part of his Gettysburg Address on Thursday November 19, 1963.

Reports Amnesty International. (2011). Nigeria: Prisoners' rights systematically flouted 2008. Retrieved June 30, 2011, from http://www.amnesty.org

Robert, D. (1971). Poliarchy: Participation and Opposition. Yale: Yale University Press.

Rosenberg, S. W. (2007). An Introduction: Theoretical Perspectives and Empirical Research on Deliberative Democracy. In S. W. Rosenberg (Ed.), Deliberation, Participation and Democracy. London: Palgrave Macmillan. https://doi.org/10.1057/9780230591080_1

Shivute, P. (2009) The Rule of Law in Sub-Saharan Africa-An Overview. In N. Horn \& A. Bosi (Eds.), Human Rights and the Rule of Law in Namibia (p. 215).

The Bangalore Principles of Judicial Conduct. (2002). Retrieved February 12, from https://www.unodc.org/pdf/crime/corruption/judicial_group/Bangalore_principles.pdf

Transparency, N. G. (2011). The Messy State of The Nigerian Judiciary. Retrieved June 7, 2011, from http://www.transparencyng.com/index.php?option=com_content\&view $=$ article\&id $=744$ : the-messy-state-of-the-nigerian-judiciary-\&catid=116:sabella-ogbobode-abidde $\&$ Itemid $=37$

Wondwosen, T. (2008) Democracy and Elections in Africa: Critical Analysis. International Journal of Human Sciences, 5(2), 1-14.

World Justice Project index. (2016). Rule of Law Index. Retrieved March 13, 2018, from http://data.worldjusticeproject.org/

\section{Copyrights}

Copyright for this article is retained by the author(s), with first publication rights granted to the journal.

This is an open-access article distributed under the terms and conditions of the Creative Commons Attribution license (http://creativecommons.org/licenses/by/4.0/). 